\title{
ARE IFRS ACCEPTABLE FOR A DEVELOPING COUNTRY WITH SPECIFIC BUSINESS CULTURE? SUDANESE ACCOUNTANTS' ATTITUDES
}

\author{
Dejan Spasic ${ }^{* 1,3}$, Mutaz A. Abouagla ${ }^{2}$ and Vojislav Sekerez ${ }^{1}$ \\ 'University of Belgrade, Faculty of Economics, The Republic of Serbia \\ 'University of Gadarif, Faculty of Economics and Administrative sciences, Sudan \\ UUniversity of Niš, Faculty of Economics, The Republic of Serbia
}

\begin{abstract}
Developing countries are faced with a lot of challenges in providing high-quality financial reports based on modern accounting regulations and practices. With its specific colonial and postcolonial history of socioeconomic relations, Sudan is one of a few countries that has not adopted the International Financial Reporting Standards (IFRS) either as a mandatory or as a voluntary financial reporting framework. Focusing on a sample of 142 respondents, the attitudes towards the obstacles and possible benefits of introducing the IFRS in Sudan expressed by accountants working in the industry sector are examined in the paper. This research study has shown that Sudanese accountants are highly aware of the needs and benefits of the IFRS adoption. The respondents predominantly agree that the IFRS adoption would increase the FDI inflow, reduce frauds and other unlawful activities, and improve the comparability, reliability and transparency of financial information, which currently is not the case. However, the research shows that accountants in Sudan also express a high degree of skepticism, given the numerous restrictions that they believe would make the introduction of the IFRS more difficult.
\end{abstract}

Keywords: Sudan, IFRS, advantages and disadvantages, accountants' attitudes

JEL Classification: M41, M48, F63

\section{INTRODUCTION}

Like any other profession in its field of activity, accountants are the pillars of the quality improvement of financial reporting as their primary task. Depending on the legal system, business culture, tradition and

* Correspondence to: D. Spasic, University of Belgrade, Faculty of Economics, Kamenicka 6, 11000 Belgrade, The Republic of Serbia; e-mail: dejan.spasic@ekof.bg.ac.rs other factors, the role accountants play can be active, i.e. direct - in terms of creating accounting principles and standards, or passive, i.e. indirect - through an adequate application of imposed rules and a critical review of justification for them as well, which can ultimately result in exerting an influence on regulators. The quality of financial statements is assessed from the user perspective (Cohen, 2003), which is a special challenge in the conditions of dynamic changes in 
the business environment. This challenge arises equally in developed economies, where the capital market participants are under constant pressure to provide high-quality accounting information, and in developing countries. Although the largest number of organized capital markets are underdeveloped or nonexistent at all, information about the business done by an entity individually the business done by the economy as a whole in developing economies is important to all the potential investors who see their chance to make a profit by investing in the economies where resources (human and material) are usually cheap. On the other hand, in the absence of funding sources, know-how, new markets, both business owners and their state are interested in attracting new investors. Of course, financial statements are the basic "communication language".

Developing countries are being faced with a number of limitations on their way towards achieving highquality financial reporting. Sudan is a typical example of it. Historical socioeconomic, political and other circumstances have hindered the achievement of this goal (Abouagla, 2017a). In the absence of modern national accounting regulations, it is possible to apply international generally accepted accounting principles embodied in the IFRS. This global harmonization would bring a broader economic effect - foreign direct investment and ultimately the growth of the national economy. Difficulties in the IFRS adoption and implementation would certainly be numerous, both objective and subjective. In addition to the other participants who can either directly or indirectly facilitate the IFRS adoption and implementation at the national level (the Government, the capital market, auditing firms, professional associations of accountants, the chamber of commerce, etc.), accountants' readiness in practice plays an important role in having the goal achieved. In this regard, the objective of this research study is to examine Sudanese accountants' propensity for the IFRS implementation in the financial reporting of large and the listed companies in the first implementation phase.

For this purpose, two basic hypotheses with appropriate claims were set:
H1: What do Sudanese accountants consider to be the main obstacles to the IFRS adoption?

H2: What would be the benefits of introducing IFRS in view of professional accountants in Sudan?

Following the "5-Point Likert Scale" methodology, the attitudes of a total of 142 randomly selected Sudanese accountants working in the industrial sector are examined in the study via a questionnaire containing eight statements on the obstacles (H1) and four statements on the benefits (H2) of the IFRS adoption.

The case of Sudan is important for several reasons. First, Sudan is one of the 22 jurisdictions that have not adopted IFRS either as a mandatory or as a voluntary financial reporting framework, not even so for the listed companies (IFRS Foundation, 2018). The peculiarities of its corporate culture, as well as its historical socioeconomic and political heritage, account for the specificity that distinguishes Sudan from many other countries.

Furthermore, the contribution this paper makes to the literature stems from the fact that the possibilities of adopting the IFRS in Sudan are only dealt with in a few papers written in the English language (Abbas, 2012; Abouagla, 2017a; Elfaki \& Al Hassan, 2018). In addition to the said, there are but few studies dedicated to the assumptions of improving the quality of financial reporting in this country (Abdalla \& El-Basri, 2015; Abouagla \& Sekerez, 2017 Abdalla, Gadour \& Salih, 2019).

In our opinion, the findings pertaining to these issues demonstrated in this research study may increase the academic public's interest and may particularly alert Sudanese policymakers to the need to consider the IFRS adoption.

In order to achieve the research goal, to first emphasize the importance the IFRS introduction has for developing countries is considered as necessary. Through an analysis of the theoretical assumptions and empirical findings presented in the available literature, the arguments for and against changing the current practice of financial reporting in Sudan are presented in the second part of the paper. In the 
third part of the paper, the fact that it is necessary to first point out the historical background of the achieved level of financial reporting in Sudan as the basis for the development of research questions of accountants' attitudes towards the need for the IFRS introduction is highlighted. The fourth part of the paper provides us with the research results and discussion, whereas the findings are summarized, and certain recommendations are identified in the Conclusion.

\section{IMPORTANCE OF THE IFRS ADOPTION FOR DEVELOPING COUNTRIES - A LITERATURE REVIEW}

\section{The globalization of business and the obsolescence of closed national economies - the need for IFRS}

The closure of national economies has long since been overcome. So, the globalization of social and economic flows and the general achievements of the 4.0 industrial revolution, as well as many other factors, has made inevitable the convergence of accounting practices at a global level. A lack of funding, modern technology, management systems and limited market access for developing countries and their companies are a challenge, the solution to which lies in attracting foreign investment. International mergers and acquisitions, joint ventures, and other forms of business combinations and investing capital rely on companies' high-quality financial statements, especially so on their comparability with investors' reports. Mutual comparability refers not only to the formal presentation of financial statements (the item structure and marking), but also to the way individual items of assets, liabilities, equity, revenues and expenses are measured. Certainly, in the conditions of different restrictions of a regulatory nature, comparability does not necessarily imply uniformity, but it is desirable that financial statement users should be clear enough about the nature and materiality of differences in reporting between investors and investees.
Information in financial statements „can be characterized as 'a powerful and significant good' because of its importance for the adequate functioning of the capital market, thus contributing to the achievement of social welfare as the ultimate goal of every society" (Obradović, 2016, 2). A company's publicity policy should be aimed at all stakeholders, especially the existing and potential investors and creditors as well (IASB, 2018). In recent decades, a set of the International Accounting Standards Board (IASB) standards - the International Financial Reporting Standards - have emerged as a global language (instrument) of business communication. Although primarily intended for public companies, their use by other unlisted companies significantly contributes to the attractiveness of investments for investors. R. Ball (2006) points out the fact that, from the investor's point of view, the most important advantage of adopting IFRS reflects in a lower investment risk, as a result of better information on the capital market value, the elimination of international differences in financial reporting, an expected increase in the market efficiency and the removal of barriers to international acquisitions. Moreover, diversity in financial reporting may negatively affect the level of international investment (Bradshaw, Bushee \& Miller, 2004). In addition to said, although the IFRS are primarily intended for listed and large companies, even small companies feel their benefits (Lee, 2019).

Foreign Direct Investment (FDI) is one of the main measures of the attractiveness of investing in a national economy and its business entities. The general hypothesis in many studies on a sample of developing countries implies that the IFRS adoption encourages FDI, which results in the economic growth of a national economy and investees as well. A number of empirical studies have proven the positive impact of IFRS on FDI inflows (Okpala, 2012; Lungu, Caraiani \& Dascălu, 2017; Akisik, Gal \& Mangaliso, 2020; Nurunnabi, Jermakowicz \& Donker, 2020). This impact is greater in developing countries than in developed economies (Gordon, Loeb \& Zhu, 2012).

Analyzing the period from 2001 to 2016 in the context of the ASEAN countries, M. Yousefinejad, A. Ahmad, F. Md Salleh and R. Abdul Rahim (2018) find that 
„IFRS adoption attracts more foreign investments into a country", whereby "the causality test also confirms both short-run and long-run causality between IFRS and FDI inflows". On a sample of the ASEAN countries in another study, the authors also point out the fact that "the positive relationship between the IFRS and FDI inflows provides evidence that the IFRS are an important determinant of FDI inflows and eventually economic growth" (Yousefinejad, Ahmad, Md Salleh, Abdul Rahim \& Md Azam, 2018a, 641).

No less important is the IFRS application in reducing information asymmetry (Bushman, Piotroski \& Smith, 2004; Gassen \& Sellhorn, 2006; Horton, Derafeim \& Serafeim, 2012; Turki, Wali \& Boujelbene, 2017), which reduces aversion to investment risk both with the existing and with potential investors. A. Malo-Alain, M. Aldoseri and M. Melegy (2021) provide a piece of the evidence of the improved efficiency of investment decisions after the IFRS adoption compared to the period preceding it, which may be brought into connection with greater trust among investors in relation to the information used by them in business decision-making. A number of studies prove the expectations that the IFRS introduction will improve the quality of accounting information (Barth, Landsman \& Lang, 2008; Horton et al, 2012). Under the IFRS application conditions, analysts' forecasts are becoming more accurate (Jiao, Koning, Mertens \& Roosenboom, 2012), inter alia due to better disclosures, which may ultimately result in „less dispersion among individual analyst forecasts and less volatility in forecast revisions" (Lang \& Lundholm, 1996). There are, however, the findings that the IFRS adoption cannot immediately result in better business decisions, fueled by financial analysts' assessments even in developed markets. H. Turki et al (2017) analyze a sample of French listed companies in the period before and after the IFRS adoption and find that financial analysts' errors decrease from the third year after the date of the first adoption.

Although the stock exchange listing and the stock exchange itself are expected to improve the quality of financial reporting, there are the opinions that the nonexistence or underdevelopment of capital markets in developing countries cannot be viewed as a factor of influence. The influence exerted by those stakeholders who, due to their "power, legitimacy or urgency" (Tawiah \& Boolaky, 2019, 574) require the disclosure of better-quality financial statements is much bigger.

Developing countries rich in oil, with the growth potential of the national economies, are showing a greater interest in harmonizing their national financial reporting rules with the IFRS in general. In addition to the IFRS implementation, some countries are striving to proactively participate in the creation of these standards. For example, the representatives of the rich MENA countries are more represented in the IASB bodies, with the clear aim of „ensuring that future accounting standards (i.e. the IFRS) and amendments to the current ones are useful to the region" (Boolaky, Omoteso, Ibrahim \& Adelopo, 2018, 331). Also, in addition to the high rate of economic growth, higher readiness to accept the IFRS in these countries is due to the high education level in general, professional accountants in particular, as well as the common law system (Zehri \& Chouaibi, 2013), as a consequence of the colonial status of such a legal system.

\section{The IFRS adoption and application possible shortcomings and difficulties}

There are, however, the perceptions that the global accounting language plays only a partial role in improving the comparability of accounting information (Leuz, 2003; Burgstahler, Hail \& Leuz, 2006). M. Nnadi and T. Soobaroyen (2015) analyze a sample of 34 African countries over a period of 20 years and find a hint of the negative impact of the IFRS full adoption on FDI. The authors believe that „in the case of Africa, foreign investors appear to be concerned with the costs of operating in an IFRSregulated environment. Secondly, fundamental institutional structures such as the rule of law, the legal system and the level of corruption, rather than the IFRS adoption, appear more important in sustaining or enhancing the level of FDI in African countries". S. Gu and G. J. Prah (2019) also deal with a sample of the 12 African developing countries that are 
the largest FDI recipients in Africa and they find that "the non-fully-IFRS-adopted countries experience higher FDI inflows than the fully-IFRS-adopted countries".

However, mixed findings may also be due to the fact that FDI inflows in African countries or in the other analyzed countries were low in many cases (Emeni, 2014), so no general conclusions can be drawn. Specifically, in some African countries, there is a positive, but insignificant correlation between FDI inflows and the IFRS adoption. Nevertheless, there is certainly an indirect connection. L. A. Gordon et al (2012) consider the effort to obtain financial assistance from the World Bank to be the primary motivation for the IFRS adoption in developing countries. Therefore, the influence of international financial institutions is no less important when speaking about the IFRS introduction in developing countries (Elad, 2015).

A lack of the institutional and professional capacities is considered to be the biggest obstacle to the IFRS implementation in Africa (Tawiah, 2019). Also, the complexity of the IFRS introduction process may be discouraging for underdeveloped countries (Guerreiro, Rodrigues \& Craig, 2020). In addition, the costs of implementation in the conditions of scarce financial resources can be a significant factor. In this regard, there is a challenge of education both during formal education at a college level and at a university level, especially implying the continuous professional education of accountants. F. Zehri and J. Chouaibi (2013) find that "developing countries with a high economic growth rate, a high level of education and a common-law system are the most favorable to the adoption of the IFRSs".

Even if IFRS were labeled as universal guidelines for the highest-quality financial reporting, "the unequal effectiveness of incentive mechanisms, together with the flexibility of IFRSs themselves and their modifications when incorporated into national regulatory frameworks, is a factor of inconsistent (uneven) application of the IFRS worldwide, which has imposed itself as a significant problem in recent years" (Obradovic, 2014). Finally, there are the opinions that "the pros and cons of the IFRS are, therefore, somewhat conjectural, the unbridled enthusiasm of allegedly altruistic proponents notwithstanding the notion that uniform standards alone will produce uniform financial reporting seems to be naïve" (Ball, 2006, 5).

Despite the IFRS-related limitations, however, (the specifics of each country where they are applied: in terms of the legal system, business culture and tradition, etc. and their incompleteness and contradictions between the requirements of different standards (Todorović \& Pantelić, 2014)), the application of these standards allows investors lower information costs, especially in the case of crossborder investments (Covrig, Defond \& Hung, 2007).

\section{RESEARCH FRAMEWORK}

\section{The Sudanese financial reporting environment}

The American Accounting Association has identified the eight elements that determine a country's accounting practice: „the political system, the economic system, the degree of economic development, financial reporting goals, the authority that prescribes accounting standards, education, the training and licensing of accountants, the application of accounting and ethical standards and client requirements" (Walton, Haller \& Raffournier, 2003, 25). For countries like Sudan, each of these elements has a significant influence on the underdevelopment of financial reporting regulations and practices. M. A. Abouagla (2017), for example, lists the following key factors that have affected the historical development and the current state of low-quality financial reporting in Sudan:

- the colonial status in the past - As a former British colony, accounting in Sudan is still based on the UK Financial Reporting Standards (especially the SSAP), the regulations that are still in force (e.g. the Companies Act of 1925), the reporting format "without any concern as to whether they meet local users' needs or level of understanding" (Abouagla, 2017, 38). 
- culture - As a typical representative of a traditional collectivist society focused on the wellbeing of the extended family, the Sudanese culture emphasizes interdependence, the connection between the members of the immediate community, which affects the tendency towards lower transparency in financial reporting to external stakeholders.

- the political circumstances - In the period after gaining independence, namely in the period since 1956, the military regime rule has been predominant (for as many as 50 years) with the instability of the entire sociopolitical system due to the civil wars and other conflicts (including the secession of South Sudan). Such circumstances were characterized by insufficient will and institutional preconditions for making changes in the financial reporting area, equally so in relation to regulations and in practice as well.

- the economic factors - of course, the sociopolitical system instability has resulted in the underdevelopment of the economy itself. After the secession of South Sudan in 2011, Sudan was left without the three-fourths of its oil revenues, which further boosted inflation, worsened macroeconomic stability and the business environment in general. In addition to that, the narrow ownership structure of Sudanese companies (large state-owned companies, small family-type companies), together with the political circumstances, have further conditioned foreign investors' low interest, thus ranking Sudan $171^{\text {st }}$ country (out of 190 countries) according to the World Bank Doing Business indicators for the year 2020 (World Bank, 2020).

- the funding system and the capital market underdevelopment - macroeconomic instability, inflation and an inadequate deposit structure favor supplying short-term loans to Sudanese commercial banks, the number of which is insufficient for the economy. In addition, the Khartoum Stock Exchange is underdeveloped, with a small number of listed companies. The listed companies' reporting non-transparency with irregular (usually made once a year) and often unaudited basic financial statements (the income statement and the balance sheet, without any notes and any other reports) reflects the general state of the financial reporting practices in Sudan.

E. E. Motwali (2005) and T. Elhassan and B. Braima (2020) emphasize the need to attract foreign investors and encourage local investors on the Sudanese Khartoum Stock Exchange to ensure the economic growth of the national economy. However, the adequate application of the international GAAP is one of the conditions for attracting foreign investors.

The fact that, unlike the industrial sector, banks and other financial institutions in Sudan, as well as those in more than 45 Islamic countries, apply the standards of the supranational body established in 1991 - the Accounting and Auditing Organization for Islamic Financial Institutions (AAOIFOI) that issues the standards covering the areas of Shari'ah, accounting, auditing, ethics and governance for international Islamic finance should be emphasized. It is understandable that radical changes in the IFRS introduction cannot be expected in the financial sector, because these standards "cannot be used to account for the accounting requirements of Islamic banking operations arising from Shari'ah compliance contracts and products" (Ahmed, Tajul Ariffin, Karbhari \& Shafii, 2019, 867).

\section{Hypotheses, methods and sample}

Hypotheses. The current state of financial reporting in Sudan described in the previous section, the need for the better and more transparent reporting of companies with the aim of attracting investors and economic growth, as well as some other shortcomings, impose the need to consider the possibility of introducing the internationally accepted accounting principles. Although, as a former British colony, Sudan has a certain legacy of the influence of the UK accounting standards, on the one hand, without their consistent application, on the other, the fact that, in the last three decades, the IFRS have increasingly been accepted either as a global trend or on a voluntary basis already in as many as 166 
jurisdictions worldwide as the standards to be applied to individual entities (e.g. listed and large companies) should never be forgotten (IFRS Foundation, 2018). Given the fact that Sudan does not belong to this group of countries, there is the need to examine the readiness of the most important participants in the financial reporting process for the IFRS adoption and implementation. As one of the pillars of each country's financial reporting system, the accounting profession certainly "plays a fundamental role in national capital markets and in assisting countries in their economic growth and development" (IFAC, 2010, 11). At the same time, accountants' readiness for changes intended to raise the quality of financial reporting is one of the crucial expected features. This paper intends to examine Sudanese professional accountants' views of a possible IFRS application.

The method. A questionnaire was created for the purpose of doing research in accountants' attitudes towards the previously defined questions. Starting from the previously researched main influential factors representing the obstacles to and the benefits of the IFRS introduction, and taking into account the described characteristics of the financial reporting environment in Sudan, each questionnaire contains a number of items divided into two groups. With respect to $\mathrm{H} 1$, the first part of the questionnaire includes the eight items that can be considered as the most important for assessing the existence of the obstacles to the IFRS adoption in Sudan. The second part of the questionnaire (H2) contains the four items that reflect the potential benefits of the IFRS introduction in this country. An overview of the claims for both research questions is given in the tables 1 and 2, where the research results are described.

The respondents were offered an item in five ways, following the "5-Point Likert Scale" methodology (Likert, 1932) that provides a reliable tool for understanding the nature of the obtained responses. The internal consistency of the responses in both tests was put to the test using Cronbach's alpha coefficient. For the first questionnaire (H1), the coefficient value was 0.83 , whereas for the second questionnaire (H2), the coefficient value was 0.91 , which indicated the satisfactory reliability of the selected instrument. The results of the research were obtained by means of the SPSS v.23.0 software package and using descriptive statistics for their interpretation.

The sample. In addition to the Sudanese agricultural sector, the industrial sector of Sudan is the Sudanese sector with the largest number of the employed and the same also has the biggest share in the GDP of the country (Central Bank of Sudan, 2018). The agricultural sector was not taken into consideration because, apart from but a few large companies, the SMEs and entrepreneurs operating in rural areas have the biggest share in the total number of the entities doing business in that sector (World Bank, 2020a, 49). The case is similar to the other, less significant sectors of the Sudanese economy, which is the reason why the questionnaires were distributed to professional accountants from the industrial sector. Using the random sampling technique, a total of 86 companies from throughout Sudan were first selected and 172 questionnaires were sent to them (to be completed by two respondents in each). Responses to 150 questionnaires were received, of which eight questionnaires proved not to be valid (with the largest number of the answers missing). There were 142 questionnaires deemed as valid for the interpretation of the results of this research study. In terms of academic qualification, the biggest number of them were filled out by the accountants with a bachelor's degree -91, only to be followed by those with a master's degree - 40, a vocational school degree - 10 and one accountant with a doctoral degree. According to their work experience, the structure of the respondents is as follows: 99 respondents had an experience of over 10 years; 21 respondents had an experience from five to ten years, whereas 22 respondents had an experience of less than five years. The authors of the paper opine that the sample is relevant, because the high level of education and the work experience of the largest number of the respondents should ensure the reliability and relevance of the collected data. The research study was conducted in the period from June to August 2017. 


\section{Results and Discussion}

H1 - Although it is considered that "the harmonization of national accounting systems with the international ones is inevitable" (Ranđelović \& Đukić, 2018), this process is slowed down by objective circumstances, i.e. a country's specifics, such as those of Sudan, which is also possible to conclude based on the analysis of Sudanese professional accountants attitudes towards the obstacles to the IFRS introduction and implementation (Table 1).

The Sudanese accountants' perceptions of the barriers to the IFRS application largely coincide with the experiences of even those developing countries that have already adopted the IFRS, such as Jordan. In that country, the barriers to the IFRS implementation originate from the weaknesses of the institutions and instability in the country itself (Al-Htaybat, 2018), on the one hand, with the "unavailability of relevant skilled individuals to carry out accounting transactions as stated by the new standard (IFRS)" being particularly pronounced, on the other (Almubaydeen, 2020, 216; similar findings can also be found in Ballas, Skoutela, \& Tzovas, 2010; Jones \& Finley, 2011). Institutional barriers, as well as mistrust in the IFRS, have also been identified as the barriers to the IFRS implementation in Egypt (Elbannan, 2011) and in African countries generally (Lassou \& Hopper, 2016; Tawiah, 2019; Agyei-Boapeah, Machokoto, Amankwah-Amoah, Tunyi \& Fosu, 2020).

In the conditions of insufficient financial resources, the inevitability of organizing training courses for accountants for the purpose of applying the IFRS and the costs associated with such activities would be a significant factor which might slow down the application of these standards in Sudan. This is the problem being faced by almost all countries (Taylor, 2009; Ballas et al, 2010; Jones \& Finley, 2011), especially by the countries whose concepts and general accounting philosophy differ from those of the IASB.

Table 1 The barriers to the IFRS application in Sudan

\begin{tabular}{|c|c|c|c|c|c|c|c|c|}
\hline $\begin{array}{l}\text { The barriers influencing the IFRS } \\
\text { application }\end{array}$ & N & Mean & S.D. & $\begin{array}{l}\text { Strongly } \\
\text { agree } \\
\text { (data in \%) }\end{array}$ & $\begin{array}{l}\text { Agree } \\
\text { (data } \\
\text { in \%) }\end{array}$ & $\begin{array}{l}\text { Neither } \\
\text { agree nor } \\
\text { disagree } \\
\text { (data in \%) }\end{array}$ & $\begin{array}{l}\text { Dis- } \\
\text { agree } \\
\text { (data } \\
\text { in \%) }\end{array}$ & $\begin{array}{l}\text { Strongly } \\
\text { dis-agree } \\
\text { (data in \%) }\end{array}$ \\
\hline & & & & $(5)$ & (4) & (3) & $(2)$ & (1) \\
\hline $\begin{array}{l}\text { The disadvantages of the regulatory } \\
\text { system }\end{array}$ & 142 & 4.03 & 0.64 & 20.18 & 64.04 & 14.04 & 1.75 & 0.00 \\
\hline Weaknesses in accountants' education & 142 & 3.68 & 0.83 & 7.89 & 68.42 & 7.89 & 15.79 & 0.00 \\
\hline $\begin{array}{l}\text { Professional accountants' inadequate } \\
\text { professional skills }\end{array}$ & 142 & 3.05 & 1.10 & 12.28 & 26.32 & 15.79 & 45.61 & 0.00 \\
\hline $\begin{array}{l}\text { The ownership type (predominantly } \\
\text { family-owned companies) }\end{array}$ & 142 & 3.75 & 1.21 & 28.07 & 45.61 & 8.77 & 8.77 & 8.77 \\
\hline $\begin{array}{l}\text { IFRS are unsuitable due to different } \\
\text { corporate cultures }\end{array}$ & 142 & 3.96 & 1.10 & 36.84 & 38.60 & 12.28 & 7.89 & 4.39 \\
\hline $\begin{array}{l}\text { Islamic banks and other financial } \\
\text { institutions should follow the Islamic } \\
\text { accounting standards (AAOIFOI) }\end{array}$ & 142 & 3.89 & 0.82 & 22.81 & 49.12 & 23.68 & 3.51 & 0.88 \\
\hline $\begin{array}{l}\text { Additional training for accountants } \\
\text { to understand and apply the IFRS is } \\
\text { inevitable }\end{array}$ & 142 & 4.50 & 0.52 & 50.88 & 48.25 & 0.87 & 0.00 & 0.00 \\
\hline A high cost of the IFRS implementation & 142 & 4.30 & 0.89 & 48.25 & 40.35 & 7.89 & 0.00 & 3.51 \\
\hline
\end{tabular}

Source: Authors 
In addition to the aforementioned factors, the most pronounced obstacle to the IFRS adoption and implementation in Sudan is conditioned by traditional business culture and social values, which is understandable because this factor generally exerts a big influence in all countries (Gray, 1988; Doupnik \& Tsakumis, 2004), especially in the societies based on the closed-type family businesses, dominant cultural values in relation to the financial reporting purpose and the other characteristics that have already been described in the previous part of the paper. "Clearly, in the current interconnected and interdependent global, economic and political environment, the idea of an underlying, cultural accounting values orientation represents but one of a variety of competing factors influencing the adoption of IFRS" (Borker, 2013, 175).

H2 - Examining the attitudes of the accountants working in the industrial sector in Sudan towards the possible benefits of the IFRS adoption and application, the results presented in Table 2 were obtained.

Table 2 makes it possible to conclude that the results are encouraging, because the Sudanese professional accountants included in the survey proved to be highly aware of the usefulness of the IFRS adoption. Therefore, it is believed the decision to adopt the IFRS for certain Sudanese entities would be encouraged by the activities carried out in said profession in terms of appropriate additional education and training on the application of these standards. Simultaneously, as the IFRS application is mainly limited to public companies and large companies, such a strategy could be defined for the convergence of the Sudanese financial reporting system with globally applied standards.

All the four claims defined as the benefits arising from the IFRS adoption are in line with the results of other research studies (Gordon et al, 2012; Yousefinejad et al, 2018a; Barth et al, 2008). Thus, raising the general level of financial reporting quality and opening companies and the country as a whole to investors and to other markets by applying IFRS have been recognized by accountants as an important goal in boosting Sudan's economy.

\section{CONCLUSION}

In the absence of their own funding sources, markets, technology and the other business success factors, developing countries strive for the convergence of their business models with developed economies and, in connection with that, the financial reporting

Table 2 The benefits of a potential IFRS implementation in Sudan

\begin{tabular}{l|cccccccc}
\hline & N & Mean & S.D. & $\begin{array}{c}\text { Strongly } \\
\text { agree } \\
\text { (data in } \%)\end{array}$ & $\begin{array}{c}\text { Agree } \\
\text { (data in } \%)\end{array}$ & $\begin{array}{c}\text { Neither } \\
\text { agree nor } \\
\text { disagree } \\
\text { (data in \%) }\end{array}$ & $\begin{array}{c}\text { Dis- } \\
\text { agree } \\
\text { (data } \\
\text { in } \%)\end{array}$ & $\begin{array}{c}\text { Strongly } \\
\text { dis-agree } \\
\text { (data in \%) }\end{array}$ \\
\hline & & & & $(5)$ & $(4)$ & $(3)$ & $(2)$ & $(1)$ \\
\hline $\begin{array}{l}\text { A contribution to attracting } \\
\text { FDI }\end{array}$ & 142 & 4.44 & 0.85 & 57.75 & 35.21 & 2.82 & 1.41 & 2.82 \\
$\begin{array}{l}\text { The reduced possibility of } \\
\text { illegal activities (frauds) }\end{array}$ & 142 & 4.32 & 0.99 & 52.82 & 38.03 & 3.52 & 0.00 & 5.63 \\
$\begin{array}{l}\text { Improving the } \\
\text { comparability of financial } \\
\text { statements }\end{array}$ & 142 & 4.46 & 0.78 & 54.93 & 41.55 & 0.70 & 0.00 & 2.82 \\
$\begin{array}{l}\text { The transparency and } \\
\text { reliability of financial } \\
\text { statements }\end{array}$ & 142 & 4.49 & 0.78 & 57.75 & 38.73 & 0.70 & 0.00 & 2.82 \\
\hline
\end{tabular}


manner. By doing so, this need is primarily economically based, although there are also political influences on the IFRS introduction (Hamidah, Triyuwono, Sukoharsono \& Djamhuri, 2015; Boolaky \& Hooi, 2016). The benefits of the IFRS introduction have been proven in a number of studies over the past two decades, and academic debate has intensified ever since. Certainly, there is the empirical evidence that the IFRS introduction has not led to the expected results. The convergence of national accounting practices at the global level, however, is inevitable because the closure of national economies is impossible in modern business conditions. The level of mutual convergence will depend on the willingness to renounce some of companies' traditional business postulates and publicity policies.

It is a special challenge for developing countries to face change in understanding the financial reporting goal, which is often conditioned by tradition, culture in general and the owner's business philosophy that financial information is not provided to a broader audience. Certainly, "the amount of variance of a country's accounting value profile with the IFRSfavorable profile is not a predictor of the speed or ultimate success of IFRS adoption or implementation" (Borker, 2013, 175). Therefore, the countries like Sudan should not be condemned in advance for not yet being able to adopt IFRS, at least not so for large and listed companies. In the postcolonial period in Sudan with all of its socioeconomic and political problems, no progress could have been made in the financial reporting field. A lack of institutional will and support and the underdevelopment of professional accounting associations account for the most important subjective factors of lagging behind in relation to the modern achievements of accounting regulations and practice.

This research study has shown that Sudanese industrial sector accountants are highly aware of the needs to adopt and the benefits of adopting the IFRS. The respondents dominantly agree that the IFRS adoption would generate a greater FDI inflow, reduce frauds and other unlawful activities, improve the comparability and reliability of financial information, and its transparency, which is currently not the case. However, the research study has revealed that Sudanese accountants also demonstrate a high degree of skepticism, given the many constraints they consider will hamper the IFRS introduction (deficiencies in the regulatory system, the inadequacy of accountants' formal and nonformal education, the inadequacy of the IFRS for the Sudanese business culture and tradition, high costs of implementation, and so on).

Nevertheless, notwithstanding any objective limitations, that the Sudanese Government, the Khartoum Stock Exchange, the professional associations of accountants and the other influential factors in Sudan should be supportive of the efforts made towards the IFRS introduction for listed and large companies is considered to be necessary. Individual efforts cannot yield results without comprehensive institutional support. The costbenefit analysis of the IFRS introduction should not be short-term in character. Although the first effects of investing in the IFRS adoption and implementation can be expected to appear relatively quickly, the full meaning of this activity would only be visible in a medium term.

The contribution of this research study is twofold. First, we believe that a study of this kind can be an additional incentive for policymakers in Sudan (the Government, the stock market and other influential bodies) to understand the benefits of the IFRS adoption and to accelerate this process. The results of this research study show that the IFRS adoption is possible in Sudan from the point of view of the accountants included in the research study sample. The obstacles identified in this study should help the stakeholders responsible for the adoption and implementation of the mentioned standards (most notably the Government and the professional associations of accountants) to create reasonable conditions for the success of this process (for example, trained educators, financial and organizational resources). Second, by contributing to the global research fund, it is expected that a further debate on whether the IFRS are universal or not, or whether the specificities of a country's corporate culture should be further taken into account in their local adoption or not, which is in particularly the case in Sudan, will be stimulated. 
There are also several limitations to this study.

First, accountants from certain sectors are not included in the survey, which might lead to a selection bias, even if the sample represents one of Sudan's largest economic sectors.

Second, although less complex than full IFRS, the accountants' views of the possibilities of adopting and applying the IFRS for SMEs in Sudan are not considered. Namely, it is believed that the simultaneous introduction of the IFRS and the IFRS for SMEs would be challenging for several reasons. In our opinion, it may pose even greater challenges before the accounting profession and all the other participants in this process than the implementation of the full IFRS in the first place. As in the largest number of other countries, micro-, small and medium-sized enterprises dominantly operate in Sudan. Therefore, there is an extremely large number of the accountants who should be trained on how to apply the IFRS for SMEs. That would cause big organizational difficulties and extremely high costs for both the state and SMEs. In addition, according to the latest published Analysis of the IFRS Foundation (2018), only 86 of 166 jurisdictions require or permit the use of the IFRS for the SME Standard (IFRS Foundation, 2018). This fact confirms the position declared in this research study that the simultaneous introduction of IFRS and the IFRS for SMEs in a country without a well-established education and training infrastructure and other essential prerequisites, such as Sudan, would be risky and likely inadequate. Following the model of developed economies, the implementation of the IFRS for large and listed companies should be the first step. In the next phase, when certain experience has already been gained and when the awareness of the usefulness of the IFRS has already increased, the implementation of the IFRS for SMEs should be performed.

Bearing in mind all the foregoing limitations, future studies should examine Sudanese accountants' attitudes towards the IFRS adoption in other economic sectors as well. In addition to said, although it is believed that only the IFRS for large and listed companies should be adopted in the first phase, it is necessary that attitudes towards the usefulness of adopting the IFRS for SMEs should be explored. Finally, it would be very useful to examine the views of the other participants in the process of adopting and implementing both the IFRS and the IFRS for SMEs (e.g. business owners, academics).

\section{REFERENCES}

AAOIFI. (2017). Accounting and auditing standards for Islamic financial institutions. Retrieved April 28, 2021, from http:// aaoifi.com

Abbas, N. H. (2012). Environmental factors influencing financial reporting practices and development in Sudan. Gezira Journal of Economic and Social Sciences, 3(1\&2), 2-32.

Abdalla, S. M. D., \& El-Basri, M. T. H. (2015). Reading and Understanding Financial Reports in the Sudan: Extent and Difficulties. Gezira Journal Of Economic And Social Sciences, 6(1), 1-16.

Abdalla, S. M., Gadour, W. H., \& Salih, K. Y. (2019). The relationship between adjusting financial statements and the shortcomings in these statements: A case study of Sudan. International Journal of Applied Engineering Research, 14(24), 4422-4433.

Abouagla, M. A. (2017). Environmental factors affecting accounting practices in developing countries: Evidence from the Sudan. Limes plus. Journal for Social Sciences and Humanities, 14(3), 31-47.

Abouagla, M. A. (2017a). The current state and perspectives on financial reporting in Arab countries - The Sudan as a case study. Unpublished Doctoral dissertation, University of Belgrade, Faculty of Economics

Abouagla, M. A., \& Sekerez, V. (2017). An overview of financial reporting in Sudan: Status and suitability. In Proceedings from 12th International Scientific Conference "Knowledge Without Borders" (pp. 63-69). Serbia, Vrnjacka Banja: Institute of Knowledge Management.

Agyei-Boapeah, H., Machokoto, M., Amankwah-Amoah, J., Tunyi, A., \& Fosu, S. (2020). IFRS adoption and firm value: African evidence. Accounting Forum, 44(3), 238-261. doi.org/ 10.1080/01559982.2020.1766755 
Ahmed, H., Tajul Ariffin, F. A., Karbhari, Y., \& Shafii, Z. (2019). Diverse accounting standards on disclosures of Islamic financial transactions: Prospects and challenges of narrowing gaps. Accounting, Auditing \& Accountability Journal, 32(3), 866-896. doi.org/10.1108/AAAJ-10-2015-2266

Al-Htaybat, K. (2018). IFRS adoption in emerging markets: The case of Jordan. Australian Accounting Review, 28(1), 2847. doi.org/10.1111/auar.12186

Almubaydeen, T. H. (2020). Evaluating the adoption of IFRS by the economies of developing countries: Case study of Jordanian firms. International Journal of Business and Social Science, 11(3), 212-217. doi:10.30845/ijbss.v11n3p25

Akisik, O., Gal, G., \& Mangaliso, M. P. (2020). IFRS, FDI, economic growth and human development: The experience of Anglophone and Francophone African countries. Emerging Markets Review, 45, 100725. doi.org/10.1016/j. ememar.2020.100725

Ball, R. (2006). International Financial Reporting Standards (IFRS): Pros and cons for investors. Accounting and Business Research, 36(1), 5-27, doi.org/10.1080/00014788.2006.9730040

Ballas, A. A., Skoutela, D., \& Tzovas, C. A. (2010). The relevance of IFRS to an emerging market: Evidence from Greece. Managerial Finance, 36(11), 931-948. doi.org/10.1108/03074351011081259

Barth, M. E., Landsman, W. R., \& Lang, M. H. (2008). International accounting standards and accounting quality. Journal of Accounting Research, 46(3), 467-498. doi.org/10.1111/ j.1475-679X.2008.00287.x

Boolaky, P. K., Omoteso, K., Ibrahim, M. U., \& Adelopo, I. (2018). The development of accounting practices and the adoption of IFRS in selected MENA countries. Journal of Accounting in Emerging Economies, 8(3), 327-351. doi.org/10.1108/JAEE-07-2015-0052

Boolaky, P., \& Hooi, G. (2016). IFRS adoption in Pacific Island Economies: A political perspective. Journal of Governance and Regulation, 5(2), 28-33. doi.org/10.22495/jgr_v5_i2_p3

Borker, D. R. (2013). Is there a favorable cultural profile for IFRS? An examination and extension of gray's accounting value hypotheses. International Business \& Economics Research Journal (IBER), 12(2), 167-178. doi.org/10.19030/iber. v12i2.7629
Bradshaw, M. T., Bushee, B. J., \& Miller, G. S. (2004). Accounting choice, home bias, and U.S. Investment in non-U.S. firms. Journal of Accounting Research, 42(5), 795-841. doi10.1111/ j.1475-679X.2004.00157.x

Burgstahler, D. C., Hail, L., \& Leuz, C. (2006). The importance of reporting incentives: Earnings management in European private and public firms. The Accounting Review, 81(5), 9831016. doi.org/10.2308/accr.2006.81.5.983

Bushman, R. M., Piotroski, J. D., \& Smith, A. J. (2004). What determines corporate transparency? Journal of Accounting Research, 42(2), 207-252. doi.org/10.1111/j.1475679X.2004.00136.x

Central Bank of Sudan. (2018). 58th Annual Report 2018. Retrieved January 12, 2021, from https://cbos.gov.sd/sites/ default/files/CBOS\%20-\%2058th\%20Annual\%20Report\%20 2018.pdf

Cohen, D. A. (2003). Quality of Financial Reporting Choice: Determinants and Economic Consequences (March 2003). NYU Working Paper No. 2451/27547. Retrieved January 12, 2021, https://ssrn.com/abstract=1280710

Covrig, V. M., Defond, M. L., \& Hung, M. (2007). Home bias, foreign mutual fund holdings, and the voluntary adoption of international accounting standards. Journal of Accounting Research, 45(1), 41-70. doi.org/10.1111/j.1475679X.2007.00226.x

Doupnik, T. S., \& Tsakumis, G. T. (2004). A critical review of the tests of gray's theory of cultural relevance and suggestions for future research. Journal of Accounting Literature, 23, 1-48.

Elad, C. (2015). The development of accounting in the Franc zone countries in Africa. International Journal of Accounting, 50(1), 75-100. doi.org/10.1016/j.intacc.2014.12.006

Elbannan, M. A. (2011). Accounting and stock market effects of international accounting standards adoption in an emerging economy. Review of Quantitative Finance and Accounting, 36(2), 207-245. doi.org/10.1007/s11156-010-0176-1

Elhassan, T., \& Braima, B. (2020). Impact of khartoum stock exchange market performance on economic growth: An autoregressive distributed lag ARDL bounds testing model. Economies, 8(4), 2-16. doi.org/10.3390/economies8040086 
Elfaki, A. A. A., \& Al Hassan, M. A. T. M. (2018). The impediments to the application of International Financial Reporting Standards from the point of view of academics and professionals in the Sudan. Archives of Business Research, 6(3), 196-213. doi.org/10.14738/abr.63.4335

Emeni, F. K. (2014). Foreign direct investments and International Financial Reporting Standards Adoption in Africa. Ushus Journal of Business Management, 13(3), 27-44.

Gassen, J., \& Sellhorn, T. (2006). Applying IFRS in Germany: Determinants and consequences. Betriebswirtschaftliche Forschung und Praxis, 58(4), 365-386. doi:10.2139/ssrn.906802

Gordon, L. A., Loeb, M. P., \& Zhu, W. (2012). The impact of IFRS adoption on foreign direct investment. Journal of Accounting and Public Policy, 31(4), 374-398. doi.org/10.1016/j. jaccpubpol.2012.06.001

Gray, S. J. (1988). Towards a theory of cultural influences on the development of accounting systems internationally, Abacus, 24(1), 1-15. doi.org/10.1111/j.1467-6281.1988.tb00200.x

Gu, S., \& Prah, G. J. (2019). The effect of International Financial Reporting Standards on the association between foreign direct investment and economic growth: Evidence from selected countries in Africa. Journal of Accounting, Business and Finance Research, 8(1), 21-29. doi.org/10.20448/2002.81.21.29

Guerreiro, M. S., Rodrigues, L. L., \& Craig, R. (2020). Institutional theory and IFRS: An agenda for future research. Spanish Journal of Finance and Accounting / Revista Española de Financiación y Contabilidad, 50(1), 65-88. doi.org/1 $0.1080 / 02102412.2020 .1712877$

Hamidah, Triyuwono, I., Sukoharsono, E., \& Djamhuri, A. (2015). The hegemony of international interests on IFRS adoption in Indonesia: An accounting ecology perspective. Procedia - Social and Behavioral Sciences, 211, 104-110. doi.org/10.1016/j.sbspro.2015.11.016

Horton, J., Derafeim, G., \& Serafeim, I. (2012). Does mandatory IFRS adoption improve the information environment? Contemporary Accounting Research, 30(1), 388-423. doi.org/10.1111/j.1911-3846.2012.01159.x

IASB. (2018). Conceptual Framework for Financial Reporting. Retrieved January 11, 2021, from https://www.ifrs.org/ issued-standards/list-of-standards/conceptual-framework/
IFAC. (2010). Tools and Resources to Support the Development of the Accounting Profession. Retrieved January 12, 2021, from https://www.ifac.org/system/files/publications/files/ Tools-and-Resource-to-Support-the-Development-of-theAccounting-Profession.pdf

IFRS Foundation. (2018). Use of IFRS Standards around the world. Retrieved January 11, 2021, from https://cdn.ifrs. org/-/media/feature/around-the-world/adoption/use-ofifrs-around-the-world-overview-sept-2018.pdf

Jiao, T., Koning, M., Mertens, G., \& Roosenboom, P. (2012). Mandatory IFRS adoption and its impact on analysts' forecasts. International Review of Financial Analysis, 21(C), 5663. doi.org/10.1016/j.irfa.2011.05.006

Jones, S., \& Finley, A. (2011). Have IFRS made a difference to intra-country financial reporting diversity? British Accounting Review, 43(1), 22-38. doi.org/10.1016/j. bar.2010.10.004

Lang, M., \& Lundholm, R. (1996). Corporate disclosure policy and analyst behavior. The Accounting Review, 71(4), 467-492.

Lassou, P. J. C., \& Hopper, T. (2016). Government accounting reform in an ex-French African colony: The political economy of neocolonialism. Critical Perspectives on Accounting, 36(C), 39-57. doi.org/10.1016/J.CPA.2015.10.006

Lee, W. J. (2019). Toward Sustainable Accounting Information: Evidence from IFRS Adoption in Korea. Sustainability, 11(4), 1-17. doi.org/10.3390/su11041154

Leuz, C. (2003). IAS Versus U.S. GAAP: Information asymmetry-based evidence from Germany's new market. Journal of Accounting Research, 41(3), 445-472. doi.org/10.1111/1475-679X.00112

Likert, R. (1932). A technique for the measurement of attitudes. Archives of Psychology, 22 140, 55. Retrieved January 12, 2021, https://legacy.voteview.com/pdf/Likert_1932.pdf

Lungu, C. I., Caraiani, C., \& Dascălu, C. (2017). The impact of IFRS adoption on foreign direct investments: Insights for emerging countries. Accounting in Europe, 14(3), 331-357. doi.org/10.1080/17449480.2017.1374546

Malo-Alain, A., Aldoseri, M., \& Melegy, M. (2021). Measuring the effect of international financial reporting standards on quality of accounting performance and efficiency of investment decisions. Accounting, 7(1), 249-256. doi.org/10.5267/j.ac.2020.9.011 
Motwali, E. E. (2005). The role of accounting information in matching the needs of capital market in Egypt and the Sudan (in Arabic). University of Khartoum House Printing and Publishing

Nnadi, M., \& Soobaroyen, T. (2015). International financial reporting standards and foreign direct investment: The case of Africa. Advances in Accounting, incorporating Advances in International Accounting, 31(2), 228-238. doi.org/10.1016/j. adiac.2015.09.007

Nurunnabi, M., Jermakowicz, E. K., \& Donker, H. (2020). Implementing IFRS in Saudi Arabia: Evidence from publicly traded companies. International Journal of Accounting \& Information Management, 28(2), 243-273. doi.org/10.1108/ IJAIM-04-2019-0049

Obradovic, V. (2014). Inconsistent application of International Financial Reporting Standards. Economic Horizons, 16(3), 231-243. doi:10.5937/ekonhor1403239O

Obradović, V. M. (2016). Međunarodni standardi finansijskog izveštavanja: Globalni jezik računovođa. Kragujevac, RS: Ekonomski fakultet Univerziteta u Kragujevcu.

Okpala, K. E. (2012). Adoption of IFRS and financial statements effects: The perceived implications on FDI and Nigeria economy. Australian Journal of Business and Management Research, 2(5), 76-83.

Ranđelović, D., \& Đukić, T. (2018). Harmonization of accounting regulations in the European Union with special reference to the EU Central and Eastern European countries. Facta Universitatis, Series: Economics and Organization, 15(2), 165-176. doi.org/10.22190/FUEO1802165R

Tawiah, V. (2019). The state of IFRS in Africa. Journal of Financial Reporting and Accounting, 17(4), 635-649. doi.org/10.1108/ JFRA-08-2018-0067

Tawiah, V., \& Boolaky, P. (2019). Determinants of IFRS compliance in Africa: Analysis of stakeholder attributes. International Journal of Accounting \& Information Management, 27(4), 573-599. doi.org/10.1108/IJAIM-09-2018-0110

Taylor, D. W. (2009). Costs-benefits of adoption of IFRSs in countries with different harmonization histories. Asian Review of Accounting, 17(1), 40-58. doi.org/10.1108/13217340910956504
Todorović, M. \& Pantelić, M. (2014). Od tradicionalnog ka modernom finansijskom izveštavanju - Kolika je cena modernizacije? Teme, 38(4), 1559-1572.

Turki, H., Wali, S., \& Boujelbene, Y. (2017). IFRS mandatory adoption effect on the information asymmetry: Immediate or delayed? Australasian Accounting, Business and Finance Journal, 11(1), 55-77.

Walton, P., Haller, A., \& Raffournier, B. (2003). International Accounting. London, UK: Thomson.

World Bank. (2020). Doing Business 2020: Comparing Business Regulation in 190 Economies - Economy Profile of Sudan (English). Doing Business 2020, Washington, DC: World Bank Group.

World Bank. (2020a). SUDAN - Agriculture Value Chain Analysis, June 2020. Retrieved April 28, 2021, from http://documents1. worldbank.org/curated/en/731741593616746051/SudanAgriculture-Value-Chain-Analysis.docx

World Bank. (2020b). Economy Profile Sudan. Doing Business 2020, Washington, DC: World Bank Group.

Yousefinejad, M., Ahmad, A., Md. Salleh, F., \& Abdul Rahim, R. (2018). Causal relationship between International Financial Reporting Standard (IFRS) and foreign direct investment (FDI): A panel data analysis of ASEAN countries. Asian Journal of Accounting and Governance, 10, 6172. doi.org/10.17576/AJAG-2018-10-06

Yousefinejad, M., Ahmad, A., Md Salleh, F., Abdul Rahim, R., $\&$ Md Azam, A. (2018a). The mediating effect of information asymmetry on IFRS and foreign direct investment. International Journal of Economics and Management, 12(2), 641656.

Zehri, F., \& Chouaibi, J. (2013). Adoption determinants of the International Accounting Standards IAS/IFRS by the developing countries. Journal of Economics, Finance and Administrative Science, 18(35), 56-62. doi.org/10.1016/S20771886(13)70030-1 


\section{Received on $20^{\text {th }}$ February 2021, after revision, accepted for publication on $12^{\text {th }}$ July 2021 \\ Published online on $2^{\text {nd }}$ August 2021}

Dejan Spasic Ph.D. is associate professor at the University of Belgrade, Faculty of Economics (part-time) and full professor at the University of Niš, Faculty of Economics (part-time). The area of expertise covers scientific field of accounting, with primarily focus on international accounting (IFRS) and sustainability reporting. He is a member of the European Accounting Association and the Serbian Association of Accountants and Auditors.

Mutaz A. Abouagla Ph.D. is assistant professor at the University of Gadarif, Faculty of Economics and Administrative sciences, currently holding position of the University principal and he is a member of the University Senate. The area of expertise covers scientific field of accounting, mainly focusing on financial reporting and accounting theory.

Vojislav Sekerez Ph.D. is associate professor at the University of Belgrade, Faculty of Economics. He wrote one monograph and about thirty articles. The area of expertise in scientific research are management accounting, international accounting and sustainable development. He is a member of the Serbian Association of Accountants and Auditors and the Serbian Scientific Society of Economists. 


\title{
DA LI SU MSFI PRIHVATLJIVI ZA ZEMLJU U RAZVOJU SA SPECIFIČNOM POSLOVNOM KULTUROM? STAVOVI SUDANSKIH RAČUNOVOĐA
}

\author{
Dejan Spasic ${ }^{* 1,3}$, Mutaz A. Abouagla ${ }^{2}$ and Vojislav Sekerez ${ }^{1}$ \\ 'University of Belgrade, Faculty of Economics, The Republic of Serbia \\ 'University of Gadarif, Faculty of Economics and Administrative sciences, Sudan \\ University of Niš, Faculty of Economics, The Republic of Serbia
}

\begin{abstract}
Zemlje u razvoju se suočavaju sa mnogim izazovima u obezbeđenju kvalitetnog finansijskog izveštavanja zasnovanog na savremenim tekovinama računovodstvene regulative i prakse. Sudan, sa specifičnom kolonijalnom i post-kolonijalnom istorijom razvoja društveno-ekonomskih odnosa jedna je od manjeg broja zemalja koja nije usvojila IFRS niti kao obavezni niti kao dobrovoljni okvir za finansijsko izveštavanje. $\mathrm{Na}$ uzorku od 142 ispitanika, ispitali smo stavove računovođa u sektoru industrije o preprekama i mogućim koristima od uvođenja IFRS u Sudanu. Naše istraživanje je pokazalo da su sudanske računovođe visoko svesne potrebe i koristi od usvajanja IFRS. Dominantno je slaganje ispitanika da bi usvajanje IFRS obezbedilo veći priliv FDI, smanjilo prevare i druge nezakonite radnje, poboljšalo uporedivost, ali i pouzdanost finansijskih informacija, kao i njihovu transparentnost, što trenutno nije slučaj. Međutim, istraživanje je pokazalo da računovođe u Sudanu izražavaju i visok stepen skepticizma, s obzirom da na brojna ograničenja za koja smatraju da bi otežala uvođenje IFRS.
\end{abstract}

Ključne reči: Sudan, MSFI, prednosti i nedostaci, stavovi računovođa

JEL Classification: M41, M48, F63 